\title{
Tenthaus Oslo - en inkluderende organisatorisk modell for framtidas kulturskoleelev
}

\author{
Gry O. Ulrichsen*, \\ freelance, tilknyttet prosjekt ved Nasjonalt kompetansesenter for kultur helse og omsorg \\ (NKKHO), Seanse (HVO)
}

\begin{abstract}
Sammendrag
Hensikten med artikkelen er å bidra med kunnskap om hvordan kunstdidaktisk praksis i skolesammenheng kan forstås og utvikles. Det kunstnerdrevne initiativet Tenthaus Oslos samarbeid med grunnskoleavdelingen for minoritetsspråklige elever ved en videregående skole løftes her fram som et alternativ til mer tradisjonelle former for kunst- og formidlingsmøter i grunnskoleopplæringen og i kulturskolen. Artikkelen viser til hvordan didaktiske forhold møter strukturelle utfordringer og åpner rom der deltakende kunstnerisk praksis og pedagogiske prosesser integreres. Didaktiske komponenter som tid, rom og utveksling: gjennom det lange tidsperspektivet, lokaliseringen av atelier på skolen, et tilknyttet offentlig visningssted og utveksling mellom kunstner og lærer står fram som definerende element i det systematiske samarbeidet mellom feltene. I et tverrfaglig læringsperspektiv argumenteres det $\mathrm{i}$ artikkelen for at erfaringer fra samarbeidet har overføringsverdier til en mer generell skolekontekst, og til kulturskolens organisering og undervisningspraksiser. Artikkelen retter også oppmerksomhet mot didaktiske forhold som kan øke deltakelsen av elever med heterogen kulturell bakgrunn i kulturskolen. I en videre forstand drøftes det hvordan kunstmøter i en pedagogisk kontekst kan få betydning i et demokratisk utviklingsperspektiv. Metodologisk tilnærming er aletisk hermeneutikk der empirisk materiale genereres gjennom narrativ og kritisk dialog.
\end{abstract}

Nøkkelord: Deltakende kunstner; kunstdidaktikk; kunstmøter; relasjonell- og sosialt engasjert kunst; narrativ; interkulturell pedagogikk.

\begin{abstract}
The aim of this article is to contribute more knowledge about how arts educational practice in the school context can be understood and developed. The cooperation between Tentahaus Oslo (TO), an initiative driven by artists, and the basic education section for minority students at an upper secondary school is brought forward as an alternative to more traditional forms of encounters with art and art communication in basic education and in the voluntary music and performing arts school. The article points out how the didactic thinking meets structural challenges and opens up spaces where participatory artistic processes and pedagogical processes are integrated. Didactic components like time, space and exchange, an extended time perspective, the placement of an atelier in school, a public exhibition space attached to the atelier, as well as exchange between
\end{abstract}

^Korrespondanse: Gry O. Ulrichsen, freelance, tilknyttet prosjekt ved Nasjonalt kompetansesenter for kultur, helse og omsorg (NKKHO) og Seanse (HVO). Email: gryulrichsen@gmail.com

(C)2017 G. O. Ulrichsen. This is an Open Access article distributed under the terms of the Creative Commons Attribution 4.0 International License (http://creativecommons.org/licenses/by/4.0/), allowing third parties to copy and redistribute the material in any medium or format and to remix, transform, and build upon the material for any purpose, even commercially, provided the original work is properly cited and states its license. 


\section{G. O. Ulrichsen}

teachers and the artist, appear as constitutive elements in the systematic cooperation between the fields. In a cross curricular perpsective on learning the article suggests that experiences from the cooperation might have transfer value to a more general school context and to the organization of the music and performing arts school and its teaching practice. The article also directs the attention to didactic arrangements that might increase the amount of students with a heterogenous cultural background in the music and performing arts school. In a larger perspective the importance of encounters with art in an educational context might enhance democratic thinking. The methodological approach is aletic hermeneutics, where empirical material is generated through narrative and critical dialogue.

Keywords: Participating artist; arts education; relational and socially engaged art; narrative; intercultural education

Received: September 2016; Accepted: November 2016; Published: January 2017

\section{Funksjonelle strukturer for møtet mellom kunst og pedagogikk?}

«It is time to create relations and to leave behind the old picture of the artist studios or the school classrooms as isolated places» skriver kunstner/forsker/pedagog Kaihovirta-Rosvik i sin avhandling Images of Imagination (Kaihovirta-Rosvik, 2009, s. 177). Slik jeg tolker henne handler det om kunstnerens mulighet til å delta som en aktiv og betydningsfull aktør i skolesammenheng. Kaihovirta-Rosvik bruker konseptet deltakende kunstnere ${ }^{1}$ om kunstnere som ikke kun bringer inn egen kunstproduksjon eller utstillinger, men aktivt involverer seg i den pedagogiske konteksten de agerer $\mathrm{i}$ (Kaihovirta-Rosvik, 2009, s. 56). Møtet mellom kunst og pedagogikk preges imidlertid i mange sammenhenger av motsetninger både på et strukturelt og et didaktisk nivå. I antologien Kunstpedagogikk og kunnskapsformidling peker Rasmussen på hvordan kløften mellom pedagogikken og kunsten er symptomatisk for hvordan fagfeltene er organisert (Rasmussen, 2013). Det handler også om hvordan man definerer kunnskapen som dannes i estetiske prosesser og hvilken betydning den tillegges i de ulike sektorene. Satt på spissen kan det se ut som at det landskapet Rasmussen skisserer ovenfor gir følgende utslag: Gjennomsnittseleven i norsk skole møter kunst og kunstnere hovedsakelig i tre strukturer: 1) de har kunst og håndverk to timer hver fredag ettermiddag med lærere som ofte ikke har mer utdannelse innen feltet enn fra grunnskolen, ${ }^{2}$ 2) de besøker en kunstutstilling på et lokalt museum to-tre ganger i løpet av grunnskoleløpet der de muligens får delta i en verkstedsbasert aktivitet etter formidlerens omvisning ${ }^{3}$ eller 3) de møter profesjonelle kunstnere gjennom Den Kulturelle Skolesekken (DKS) der oppleggene i stor grad er opplevelsesbaserte og

\footnotetext{
${ }^{1}$ Teaching artist er en annen term som rammer inn arbeidet til profesjonelle kunstnere som jobber med og gjennom kunst i skoler eller andre samfunnsinstitusjoner i langsiktige og forpliktende samarbeid (Ulvund, 2015).

${ }^{2}$ Statistikk viser at mellom 30-50 \% av kunst- og håndverklærerne ikke har fagutdanning (Allern, 2011).

${ }^{3}$ Forskning peker gjennomgående på manglende struktur, systematisk organisering og integrert samarbeid mellom kunstinstitusjoner og skole (Aure, Illeris, \& Örtegren, 2009; Samuelsen, 2013).
} 
preget av monologisk formidling. ${ }^{4}$ I de to sistnevnte fokuseres det oftere på å lære om kunst enn gjennom og $i$ kunst.

Utover dette er barn og unge henvist til fritidssektoren gjennom blant annet kulturskolen for å delta i kunstdidaktiske praksiser veiledet av profesjonelle kunstnere og fagutdannede lærere. Statistikk om kulturskoledeltagelsen i Buskerud, Telemark og Vestfold viser at deltakelsen er $50 \%$ lavere blant innvandrere og elever med innvandrerforeldre enn blant den øvrige befolkningen (Kleppe, 2013). I Trondheim er deltakelsen fra elever med bakgrunn fra Asia/Afrika $22 \%$ lavere og $25 \%$ lavere i Oslo og Stavanger enn i den øvrige befolkningen (Bjørnsen, 2012). Deltakelsen settes også i sammenheng med foreldrenes utdanningsnivå. $80 \%$ av foreldrene til barn som går i kulturskole har høyere utdanning jamfør $36 \%$ for hele befolkningen. Det pekes på ulike årsaker til at deltakelsen i kulturskolen er lavere fra elever med heterogen kulturell bakgrunn. Økonomi nevnes, men sees ikke på som et av de største hindrene. Videre vurderes hvordan verdsettingen av å gi barn kunstopplæring kan variere med sosial og kulturell bakgrunn, og ulike tradisjoner for å overlate oppdragelsen til offentlige institusjoner på fritiden. Tilbudets tilgjengelighet trekkes fram som en av hovedutfordringene. Det handler både om språk, spesielt i forhold til kommunikasjon med foreldrene, og om kjennskap til systemene. I tillegg poengteres det hvordan de fleste kunstutrykkene det tilbys opplæring i primært er fundert $\mathrm{i}$ norsk og vestlig kultur (Bjørnsen, 2012; Kleppe, 2013).

Målet med artikkelen er i lys av ovenstående å bidra med kunnskap om hvordan kunstdidaktisk praksis i skolesammenheng kan forstås og utvikles. Det kunstnerdrevne initiativet Tenthaus Oslos (heretter TO) samarbeid med grunnskoleavdelingen for minoritetsspråklige elever ved en norsk videregående skole løftes fram som en alternativ organisasjonsmodell til mer tradisjonelle former for kunst- og formidlingsmøter i grunnskoleopplæringen og i kulturskolen. I artikkelens problemområde undersøker jeg hvilke rammebetingelser og strukturelle kjennetegn som konstituerer TOs og skolens samarbeid. Jeg ser spesielt på hvordan relasjonene mellom kunstnerelev-lærer dannes. På bakgrunn av den genererte empirien drøfter jeg hvilken betydning relasjonelle aspekter kan få for en kunstdidaktisk praksis i en pedagogisk kontekst og hvordan erfaringer fra samarbeidet i et tverrfaglig læringsperspektiv kan innebære overføringsverdier til en mer generell skole- og kulturskolekontekst.

\section{Kort beskrivelse av forskningssubjektet}

TO er et selvorganisert kunstnerdrevet initiativ som siden 2009 har hatt en partnerskapsavtale med den videregående skolen. De tre billedkunstnerne i TO har periodevis hatt atelier på skolen og driver et offentlig visningssted for kunst. Når andre kunstnere inviteres til å produsere prosjekter og utstillinger hos TO integreres alltid kunstmøter med elevene. Denne artikkelen omhandler TOs praksis med en fast

\footnotetext{
${ }^{4}$ Forskning rundt DKS peker på at erfaringene $i$ liten grad settes i sammenheng med skolehverdagen for øvrig eller vurderes som kunnskapsproduksjon (Bamford, 2012; Breivik og Christophersen, 2013; Kalsnes, 2011).
} 


\section{G. O. Ulrichsen}

gruppe elever og deres lærere som i tre år har deltatt i produksjoner og workshops der de på ulike måter har blitt eksponert for samtidskunst. Elevene er mellom 16-20 år, og er derfor i en videregående skole, men de går på linjen grunnskoleopplæring for minoritetsspråklige elever.

\section{Plassering i forskningsfeltet}

Det er gjort vesentlig forskning på møtet mellom kunst- og skolefeltet, både innenfor kunstinstitusjonene og i DKS, men det finnes lite forskning på relasjonelt forankrede måter å strukturere dette møtet på i undervisningspraksis. Forskning etterspør mer samhandling mellom aktørene på kunstfeltet og den pedagogiske arenaen, og peker på behov for langsiktig og strukturert samarbeid, organisatoriske modeller som bygger eierskap i begge sektorer og gjensidig forpliktelse (Aure, 2013; Aure, Berge, \& Hylland, 2012; Kaihovirta-Rosvik, 2009; Ulvund, 2015). Det etterlyses videre forskning som: «1) øker forståelsen for hvordan en sosial tilnærming til kunst og utdanning fundamenteres, 2) løfter fram bevissthet og forpliktelse blant lærere og kunstnere for å endre tilnærming og innfallsvinkler, og 3) viser effektive strategier som tilrettelegger for og oppmuntrer til sosial rekonstruksjon i opplæringen» (Costantino og Garber, 2007, s. 1064; min oversetting). I lys av ovenstående representerer forskningen et bidrag i utviklingen av fleksible og fruktbare rammebetingelser som integrerer relasjonelt forankret kunstdidaktisk praksis i grunnskoleopplæringen og kulturskolen.

\section{Den sosialt engasjerte kunstens didaktikk}

Kunst basert på sosial interaksjon har de siste tiårene blitt identifisert som relasjonell, kollaborativ, deltakende, dialogisk, offentlig og som sosial praksis. TOs virksomhet forstås i denne artikkelen gjennom begrepene rundt sosialt engasjert kunst (heretter SEK) og relasjonell estetikk. Relasjonell kunstteori ble artikulert av Bourriaud på 1990-tallet for å fange opp en kunstpraksis som i stor grad dreide seg om å skape møteplasser og sosiale situasjoner der mellommenneskelig handling og interaksjon utspant seg, ofte gjennom å agere med ulike samfunnsstrukturer og kulturarenaer (Bourriaud, 2007). I denne sammenhengen er kunstnerens rolle å være en katalysator, igangsetter og tilrettelegger og kan forenklet sees som en alternativ strategi til en kunstnerisk posisjon forankret i modernismen der kunstneren produserer objekter som presenteres innen kunstinstitusjonen.

I boken Education for Socially Engaged Art skiller Helguera mellom en representativ praksis og en reell praksis der SEK defineres av: 1) om dybden i sosiale relasjoner utvikles, 2) om den utøver og bringer fram reell sosial handling i den konteksten det opereres i, og 3) måten den gjør dette på (Helguera, 2011). Forfatteren viser til et behov for å synliggjøre sammenhengen mellom den sosialt engasjerte kunstens hvorfor, som allerede er godt utviklet som teorigrunnlag, med hva og hvordan. Artikulering og tolkning av TOs praksis sees i denne sammenhengen som et bidrag til å utvide forståelsen av hvordan en relasjonell- og sosialt engasjert kunstpraksis kan 
utøves på en pedagogisk arena, både når det gjelder å synliggjøre forbindelsen mellom kunstsyn og didaktiske elementer, og for å utvikle en didaktikk på kunstens premisser. Kunstdidaktikk forstås her som et begrep for å undersøke og vurdere kunnskapsproduksjon, og spredning i og gjennom kunst som et bredt perspektiv på læring (Aure, 2013). ${ }^{5}$ Kunnskapsutvikling $i$ en kunstdidaktisk praksis karakteriseres $i$ denne artikkelen av et transformativt potensiale og mulighetene for at nye perspektiv åpnes i møte med kunst, både som persepsjon og som produksjon av symbolsk form (Kaihovirta-Rosvik, 2009; Sava, 1995; Østern, 2013).

Den relasjonelle og sosialt engasjerte orienteringen i kunsten kan her knyttes opp mot Sidorkins og Binghams perspektiver innenfor en relasjonell pedagogikk (Sidorkin \& Bingham, 2004). I et post-positivistisk paradigme foreslår forfatterne denne tilnærmingen for å imøtekomme bevegelsen fra fokuset på generelle metoder til det partikulære: alt er ikke relativt, men alt avhenger derimot av relasjonene og relasjoner kan med fordel analyseres og beskrives. Relasjonell pedagogikk forståes som en paraply der ulike perspektiver samles rundt en felles antakelse om at relasjoner har fortrinn over det isolerte «selvet», og gjennom en interesse for å forstå menneskelige relasjoner heller enn utdanningsmessige prosesser, oppførsel, metoder og læreplaner (Sidorkin \& Bingham, 2004, s. 1-3). Fra dette perspektivet kan de estetiske erfaringene elevene gjennomgår i TOs praksis anses som en plattform for å bygge og styrke relasjoner.

\section{Narrativ og kritisk dialog som metode}

Metodologisk utvikles forskningen innenfor rammene av en aletisk hermeneutikk (Alvesson og Sköldeberg, 2008, s. 200). Den aletiske hermeneutikken vil avdekke det som er skjult gjennom en pendling mellom forforståelse og ny forståelse. Forskningsprosessen påvirkes også av en narrativ (Riessman, 2008) og kunstinfluert (Knowles og Cole, 2008) tilnærming til kvalitativ forskning. Prosessen har en abduktiv, interaktiv og praksisnær tilnærming med fokus på kollaborative aspekter mellom forskningsdeltakere og meg som forsker i ulike faser. ${ }^{6}$ Gjennom å ta forskningsdeltakerne med i analysen som et bærende element i selve prosjektets design løfter forskningen fram et interaktivt og relasjonelt kunnskapssyn. I en slik tilnærming står affekt og kognisjon i et dialogisk forhold til hverandre og ikke i et motsetningsforhold (Bresler, 2008; Rasmussen, 2012). Empirisk materiale genereres gjennom semistrukturerte intervjuer med to av kunstnerne med påfølgende dialog med utgangspunkt i foreløpige tolkninger. I tillegg har jeg brukt deltakende observasjon (feltnotater og billeddokumentasjon) og dokumentasjon som prosjektets nettside, kunstnernes utviklingslogger,

\footnotetext{
${ }^{5}$ Ifølge Venke Aure (2013) vil kunstdidaktikk istedenfor det mer tradisjonelle begrepet kunstfagdidaktikk skape forskyvning fra en didaktikkforståelse, ofte knyttet opp mot skolefag og deres læreplan, til en utvidet didaktikkforståelse.

${ }^{6}$ Liora Bresler (2008) anvender termen fortolkende sone for å skape forskyvning fra det tradisjonelle bildet av forskeren som uavhengig solo-arbeidende, mot en sosialt forankret forsker.
} 


\title{
G. O. Ulrichsen
}

samt offentlige dokumenter som rapporter og prosjektbeskrivelser. Studien er meldt inn og godkjent av NSD.

\section{Narrativer fra et kunstnerperspektiv}

\begin{abstract}
Jeg føler at gjennom å introdusere samtidskunst for nye grupper berører vi så mye mer enn hva kunst og kultur representerer. Jeg tror det handler om et generelt ønske om å utrykke seg som menneske. I møtet med samtidskunstens ulike former av utrykk kan en mulighet til å vise seg fram oppstå og en forståelse for individets plass i samfunnet trer fram. Det som er spennende er at det kan oppnås gjennom å se og prøve i praksis. I et av kunstmøtene, Patterns of Inclusion, ${ }^{7}$ deltok elevene i en filmatisering der barnesangleken slå-på-ring visualiserte hvordan et fellesskap ofte defineres ut ifra tanken om at noen utelukkes. Filmproduksjonen var også utgangspunkt for to verksteder der enkle oppgaver sirklet inn begreper som tilhørighet, ekskludering, vennskap, lojalitet og frykt. Gjennom collage, tidslinje og tankekart reflekterte elevene rundt: Hvem er jeg i felleskapet? Hvordan har jeg kommet dit jeg er nå? Kunstneren ba blant annet elevene om å ta foto av det de mente var deres felleskap. Diskusjonene i begge workshopene gikk på hvordan det var å være en del av noe annet. Så kom filmdagen og elevene var helt med. De kom på utstillingen kunstneren hadde på Tenthaus og de kom på høstutstillingen der filmen ble vist. De var ikke bare interesserte i å se seg selv, men på en måte så de seg selv i en større sammenheng også. Den måten kunstneren formidlet det konseptuelle grunnlaget av den kunstneriske ideen handlet om helt andre ting enn at elevene stod der som statister i filmen. De fikk en erfaring av kunstverket gjennom workshopøvelsen, med å være med i filmproduksjonen og å se kunstverket. De klarte å se den idemessige sammenhengen.
\end{abstract}
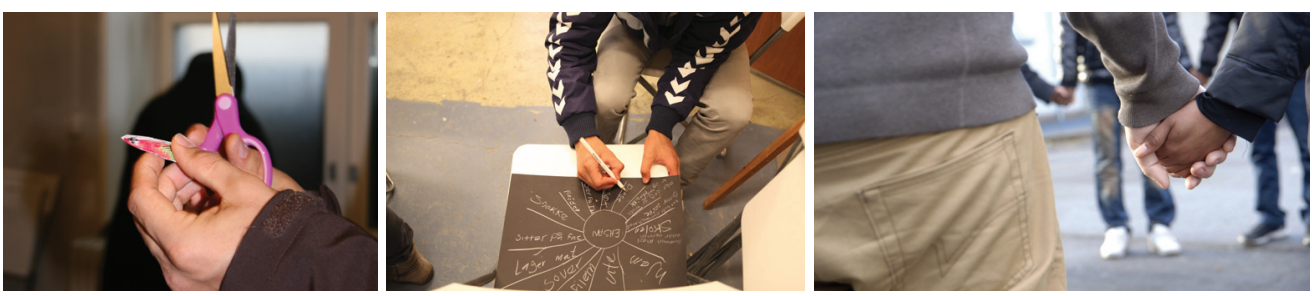

Foto: TO/Mariken Kramer

Figur 1. Kunstnernes narrativ.

I et av kunstmøtene vi selv gjennomførte lagde vi sammen med elevene og lærerne en tremeters relieff som henger på skolen. Vi så hva som kanskje manglet i våre tidligere prosjekter og bestemte oss for å giøre noe praktisk med elevene, noe vi kunne holde på med over lengre tid og som også kunne henge på skolen som et ferdig resultat. Det startet med at vi stilte en del spørsmål. Et av svarene nevnte Eufrat og Tigris. Sammen med det faktum at Akerselva renner forbi ikke langt fra skolen, ble dette et utgangspunkt. Vi undersøkte området gjennom en vandring med elevene der vi fant en del ting som ble støpt i gips. Elevene tok også med seg objekter som vi la inn. Arbeidet med relieffen utviklet seg underveis i prosessen med elevene der de fikk bestemme innenfor de rammene vi ga.

${ }^{7}$ Kunstmøtet ble ledet av billedkunstneren Mariken Kramer http://www.tenthaus.no/om-prosjek tet/mariken-kramer—patterns-of-inclusion/. Filmen kan sees på https://vimeo.com/74951843 

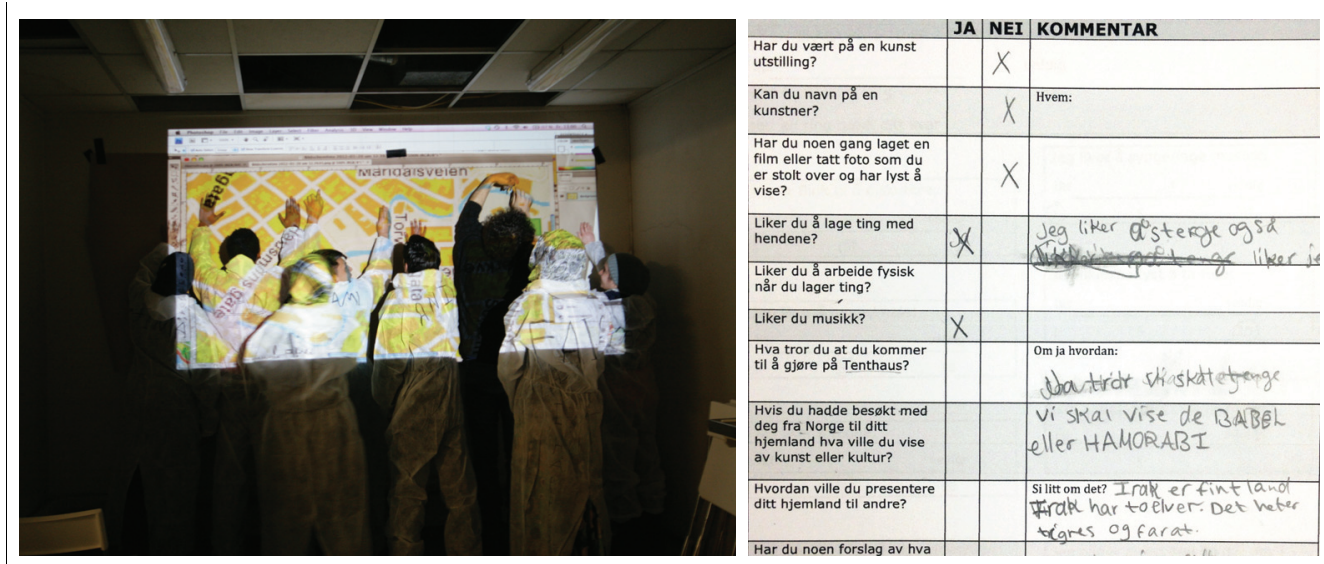

Foto: TO.

Vi har i en periode hatt atelier på skolen. Da var vi tilstede også når vi ikke har prosjekter, vi traff elevene i gangene og på do. Når kommer dere? spurte elevene. Noen ganger brukte læreren vårt atelier for å snakke med elevene. Dette skapte en nærhet som er en basis for prosjektet. Nå når vi ikke har atelier på skolen er det et stort savn. Den uformelle kontakten vi hadde var viktig for å holde prosjektet synlig blant elevene. Og vi ble hele tiden påminnet skolen og elevene som deltakere. Når vi nå sitter $\mathrm{i}$ et gallerilokale kan fokus lett skifte til kunstneren som skal stille ut. Jeg føler jeg må hente meg inn hele veien. Ok, men elevene, hvor er de? Det er et tyngre arbeid. Out of sight out of mind. Et annet spørsmål vi stiller oss er hva som skjer når kunstneren må forholde seg til begrensninger som oppstår i møtet med institusjonen. Det er tydelig at forhold i skoleverket er en vesentlig del av vår praksis. Det å utfordre rammebetingelsene innenfra, gjennom tett dialog med lærere, elever og ledelse, kan være med på å utvide mulighetene for hva og hvor kunst kan være i dag. I et av våre prosjekt ble en kunstner invitert til å lage en installasjon på skolen, men dette viste seg å by på praktiske utfordringer. Hans verk skulle være en labyrint $\mathrm{i}$ skolens kjeller hvor man lett kunne gå seg vill, men til slutt komme frem til en møteplass. Installasjonen var inspirert av minner om en forsvunnet skoletid i møte med kunstnerens eldre jeg. Utstillingen lot seg ikke gjennomføre blant annet på grunn av brannforskrifter og skolens åpningstider. Vi møtte her grensene for hva som var mulig å gjennomføre i form av kunstproduksjoner på denne skolen. Men eksemplet viser at det finnes potensial for å tilegne seg mer erfaring via grensesprengende kunst i skolesammenheng enn det å bare lage verksteder for barn og unge.

Figur 2. Kunstnernes narrativ.

\section{Didaktiske forhold i Tenthaus Oslo - tid, rom og utveksling som definerende rammefaktorer}

Når kunstpraksis utøves innenfor en pedagogisk kontekst eller presenterer seg som utdanning må man spørre seg hva læringen består av, hvordan den oppstår og under hvilke forhold (Helguera, 2011). Det er de to siste aspektene som er sentrale her. Narrativene (fig. 1 og 2) kan leses som en refleksjon over hvordan ulike didaktiske forhold påvirker praksisen i TO og belyser hvordan utviklingen og gjennomføringen av prosjektene bygger på en refleksiv praksis som er integrert på den pedagogiske arenaen og som inkluderer tilbakemeldinger fra skolen. 


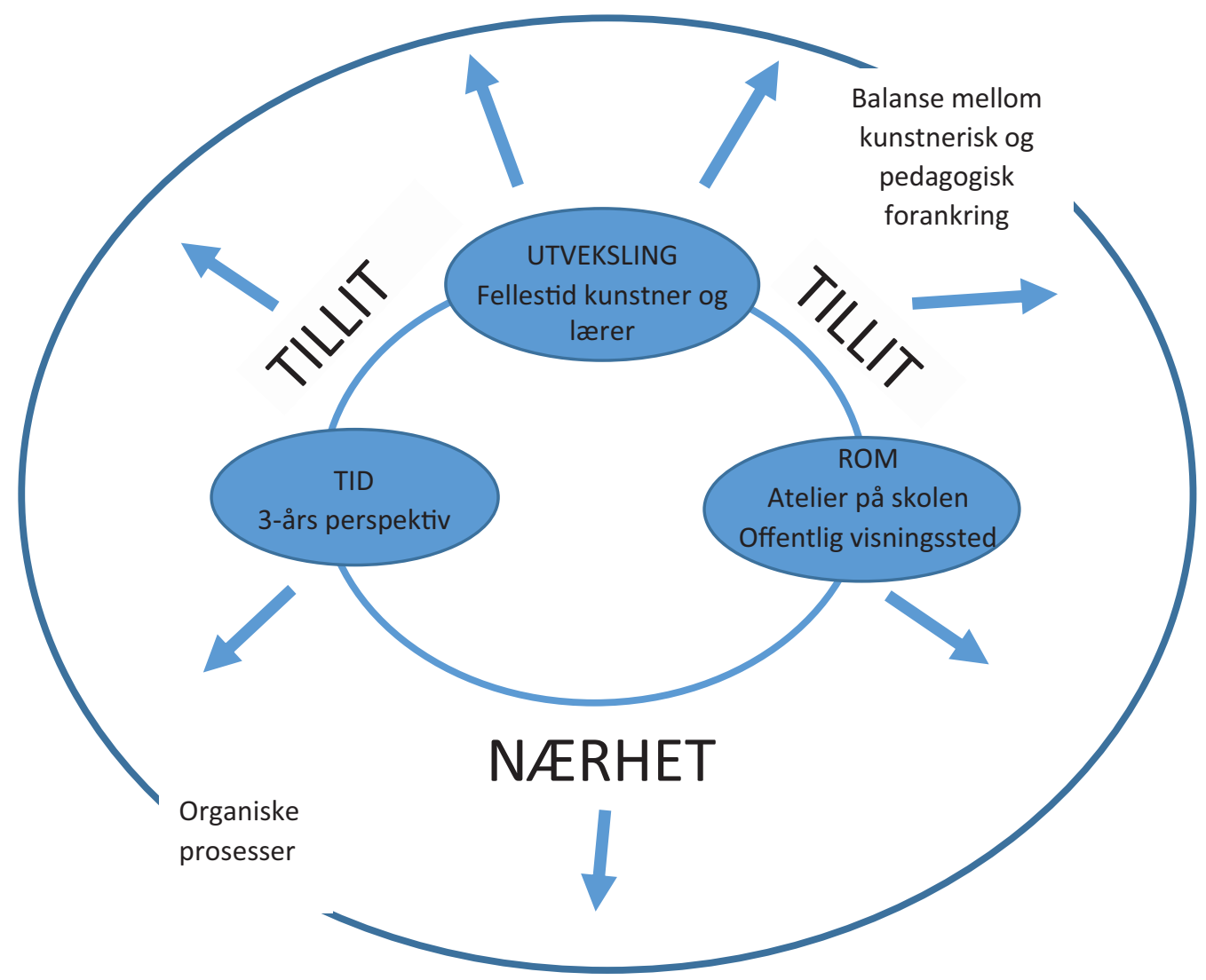

Figur 3. Didaktiske komponenter i TOs og den videregående skolens samarbeid.

Figur 3 viser hvordan de didaktiske komponentene tid, rom og utveksling står fram som definerende elementer $\mathrm{i}$ det systematiske samarbeidet mellom feltene: det lange tidsperspektivet, periodevis lokaliseringen av atelier på skolen, et fast tilknyttet offentlig visningssted og utveksling mellom kunstner og lærer. Den tilliten og nærheten mellom aktørene som oppstår under disse didaktiske forholdene ser ut til å åpne for prosessorienterte undervisningsforløp og balanserer en kunstnerisk og pedagogisk forankring (Ulrichsen, 2014). En organisk utvikling av et opplæringsforløp innenfor en relasjonell pedagogisk tilnærming innebærer ifølge Sidorkin og Bingham (2004, s. 7) utforskende læring og ekspressive mål.

\section{Relasjonelle aspekter i kunstdidaktisk praksis}

Kunstnernes narrativer (fig. 1 og 2) belyser hvordan de didaktiske komponentene tid, rom og utveksling kan danne et læringsrom som legger til rette for å bygge og styrke relasjonene mellom elev-kunstner-lærer. Innenfor en relasjonell tilnærming til læring vil det ikke bare være eleven, men like mye kunstneren og læreren som profiterer på å inngå i livgivende relasjoner (Sidorkin \& Bingham, 2004; Spurkeland, 
2011). Sidorkin og Bingham (2004, s. 7) peker på hvordan det å drive opplæring er ensbetydende med å etablere og bygge utdanningsmessige relasjoner. Mål og utbytte i opplæringen kan, ifølge forfatterne, defineres som spesifikke former for relasjoner som man utvikler til seg selv, til medelever og til omverdenen. Videre framhever de hvordan både kunnskap og autoritet bygges i dialektiske forhold der man er avhengig av at andre agerer og kommer i møte. Stabile relasjoner bygd over tid i TO anses som en forutsetning for at aktørene kan gå inn i uforutsigbare og potensielt transformative læringsprosesser (Ulrichsen, 2014). Kunst kan på denne måten spille en viktig rolle $\mathrm{i}$ elevers konstruksjon av en hybrid og fleksibel personlig og kulturell identitet (Bjerkestrand, Brahmachari, Haraldsen, Ingul \& Møller, 2016; Evron, 2007). TOs kunstdidaktiske praksis viser hvordan ambivalente og problematiske aspekter rundt kultur og identitet kan inkorporeres på en dynamisk måte. I en slik kritisk og samarbeidende praksis blir det viktig å ha etablerte relasjoner der både elever, lærer og kunstner kjenner trygghet og kan håndtere det emosjonelle kaoset som, ifølge Evron (2007), ofte oppstår når eksistensielle verdivurderinger kontrasteres. De deltakende kunstnernes tilstedeværelse i TO ser ut til å fungere som den røde tråden som knytter skole og kunstverden sammen og anses dermed som en forutsetning for å igangsette meningsskapende prosesser.

TOs praksis gir argumenter for å øke oppmerksomheten rundt relasjonene mellom kunster og lærer. Forskning på lærerens rolle i DKS tillegger lærerens holdning og innstilling stor betydning for elevenes utbytte av kunstmøtene som kunnskapsproduksjon (Breivik \& Christophersen, 2013). Lærerens rolle betegnes også av kunstnerne i TO som avgjørende for utviklingen av prosjektene. Gjennom lærerens aktive deltakelse i kunstmøtene sammen med elevene oppstår det et tillitsforhold mellom aktørene. Selv om kunstnere og lærere jobber sammen i lange tidsperspektiv, avdekker materialet at det er behov for mer felles tid mellom lærer og kunstner både i planlegging, prosess- og sluttevaluering. Kaihovirta-Rosvik (2009) løfter fram betydningen av at de ulike profesjonsutøverne som skal samarbeide har kjennskap til og innsikt i hverandres fagfelt, og at de får mulighet for å reflektere rundt sin praksis på tvers av fagfeltene. Sammensetningen mellom Tenthaus-kunstnerne, der en pedagogisk og kunstnerisk forankring balanseres, framstår her som betydningsfull for å skape rom for refleksjon og bevisstgjøring mellom de to ulike feltene. Helguera (2011, s. 30-34) peker nettopp på betydningen av å ha kjennskap til praksis og metode i utdanningen som allerede er etablert og utprøvd, slik at kunstnere ikke bare gjenoppfinner de samme strategiene på nytt innen kunstfeltet, eller baserer praksis kun på intuisjon, prøving og feiling. Å få en forståelse av hvordan de eksisterende strukturene i feltet fungerer er en forutsetning for å vite hvordan man skal interagere $\mathrm{i}$ en pedagogisk kontekst. Kunstnerne peker på praktiske og timeplanmessige utfordringer for å få til en systematisk utveksling mellom kunstnere og lærere. Sett i lys av Rasmussens (2012) beskrivelser av kløften mellom kunsten og pedagogikken kan det også handle om hva som gis betydning og hva som verdsettes i de ulike sektorene. Økt prioritering av tid for utveksling mellom lærer og kunstner ser i samarbeidet mellom TO og den videregående skolen ut til å være et kritisk moment for å videreføre og utvikle arbeidet med å skape stimulerende læringsmiljø for elevene. 


\section{G. O. Ulrichsen}

\section{Kunstdidaktisk praksis som demokratiutvikling}

Selander (2008, s. 32) peker på hvordan skolen i dag har en dobbel oppgave. I tillegg til å utdanne kunnskapsrike personer, skal man danne demokratiske medborgere som på ulike vilkår og utfra sine ulikheter kan delta i politiske diskusjoner og være aktive på den offentlige arenaen. For at unge skal delta i demokratiske prosesser må man utvikle praksiser som fremmer og involverer bruk av sosiale og kritiske ferdigheter. Transformative kunstneriske læringsprosesser kan ifølge Østern (2013), få en innvirkning på elevenes forhold til samfunnet. Illeris (2011) løfter fram en performativ tilnærming og den relasjonelle kunstens potensial for problematisering og utvikling av kulturell kompetanse i motsetning til en objektfokusert estetikk. Hun framhever videre hvordan møter i samtidskunsten ofte rommer sosialt orienterte former for kommunikasjon. De deltakende kunstnerne i TO kan forstås som en katalysator for å skape et engasjement rundt de unges rolle og plass i samfunnet. Den estetiske erfaringen som elevene tilegner seg gjennom praktiske handlinger ser ut til å være en basis for TOs praksis. Det handler likevel ikke om en disiplin- og objektbasert praksis der man oppøver ferdigheter i ulike teknikker, men mer om at man ved å gjennomgå de estetiske erfaringene sammen kan utvikle en forståelse av hvordan menneskelig erfaring og identitet konstrueres. I narrativet (fig. 1) som omhandler kunstmøtet med Patterns Of Inclusion ser man en elevgruppe som tilhører ulike minoritetskulturer og står overfor et dobbelt identitetsarbeid. I tillegg til å være ungdom med det identitetsarbeidet denne livsfasen innebærer, skal de orientere seg $\mathrm{i}$ en relativt ny kultur og skape forbindelser mellom den kulturbakgrunn de kommer fra og den nye de nå bor i (Aagre, 2003; Bjerkestrand et al. 2016). Biesta og Lawy (2006, s. 45) vektlegger hvordan kjennskap til demokratiske prosesser først og fremst må forstås ved førstehånds erfaring gjennom ulike aktiviteter i og utenfor skole og arbeidsplass. I kunstmøtene får elevene tilgang til en offentlig arena for meningsskaping og meningsutveksling. Spørsmål som reiser seg er om disse erfaringene vil føre til at elevene våger mer $\mathrm{i}$ andre ukjente og fremmede sammenhenger. En mulig konsekvens av elevenes deltakelse i den kunstdidaktiske praksisen på ulike læringsarenaer i TO kan være at de også vil delta på andre offentlige arenaer, og at de dermed utvider sine muligheter til å være med å påvirke omgivelsene rundt seg (Ulrichsen, 2016).

\section{En organisatorisk modell til etterfølgelse?}

I et av kunstmøtene observerte jeg hvordan elevene i stor grad aktiviserte seg selv. ${ }^{8}$ «Dette er en fase i prosjektet etter at vi har holdt på så lenge - de skjønner at de må gjøre noe selv for å få noe ut av det» kommenterte en av kunstnerne (Ulrichsen, 2014). En mulig slutning i lys av Illeris' (2011) betraktninger rundt kulturell kompetanse kan være at elevene, etter å ha deltatt i denne typen prosjekter jevnlig i tre år, har tilegnet seg den kompetansen som trengs og dermed er i stand til å bruke sine kvalifikasjoner på en selvstendig og uavhengig måte når de møter samtidskunst.

\footnotetext{
${ }^{8}$ Kunstmøtet ble ledet av Flatbread Society som er en del av satsningen på kunst i det offentlige rom i Bjørvika http://www.tenthaus.no/workshops/flatbread-society/
} 
Læreren peker også på utviklingstrekk over tid og beskriver hvordan elevene i starten var «negativt innstilte til både kunstnerne og deres prosjekter, mens de i dag kaster seg ut i det og tilegner seg erfaringer på kunstfeltet med en selvfølgelighet» (Ulrichsen, 2014). Å oppnå et utbytte av estetiske erfaringer krever trening (Samuelsen, 2013). Det ser ut til at elevene i samarbeid med TO har fått denne treningen, gått gjennom en tilvenningsprosess og dermed opparbeidet fortrolighetskunnskap gjennom kunstmøtene. I lys av Savas (1995) beskrivelser av en transformativ læringsprosess vil dette også kunne tolkes som en endring i elevenes mentale modeller der de strukturelt er blitt i stand til å tenke på nye måter og dermed endrer handlingsmønster.

Den kunstdidaktiske praksisen som er beskrevet i artikkelen er tuftet på didaktiske komponenter som både kan gjøre kløften mellom kunst og pedagogikk mindre, og kan møte noen av de utfordringene Kleppe (2013) og Bjørnsen (2012) peker på i en kulturskolekontekst. TO flytter for det første den kunstdidaktiske praksisen inn på skolearenaen, til elevenes hjemmebane, samtidig som klasserommet ekspanderer ut på andre læringsarenaer i samfunnet. For det andre forankres samarbeidet i langsiktige og gjensidige forpliktende prosesser mellom skole- og kunstfelt. Gjennom å styrke relasjonen og den faglige utvekslingen mellom lærer og kunstner vokser det fram en refleksiv, integrert og levedyktig kunstdidaktisk modell som skaper eierskap i begge sektorene. Det oppstår dermed unike muligheter til å utvikle et tverrfaglig potensiale i den kunstdidaktiske praksisen. For det tredje involverer en stor del av kunstmøtene i TO kunstnere som speiler elevgruppens kulturelt hetrogene bakgrunn. Kleppe (2013) peker på utvalget av kunstutrykk i kulturskolen som et mulig moment for å forklare at barn og unge med minoritetsbakgrunn har lavere deltakelse enn de med majoritetsbakgrunn. TO når med sitt utvalg av besøkende kunstnere og sin tilstedeværelse i elevenes obligatoriske skolehverdag dermed elever som selv ikke finner veien til kulturelle arenaer som kulturskolen. Dette fører til at unge, uavhengig av økonomisk, sosial eller kulturell bakgrunn, får mulighet til å delta i potensielt transformative og meningsskapende prosesser gjennom kunstdidaktisk praksis.

\section{Konklusjon og veien videre}

Artikkelens problemområde har undersøkt hvilke didaktiske komponenter som konstituerer TOs praksis. Hensikten har vært å gi innsikt i hvordan relasjonelle aspekter mellom kunstner-elev-lærer får betydning i samarbeidet mellom TO og den videregående skolen. Jeg har i artikkelen løftet fram hvordan didaktiske komponenter som tid og rom, skaper tillit og nærhet og legger til rette for å arbeide med utveksling mellom aktørene på mange nivåer. De nevnte komponentene forstås også som materiale i en kunstnerisk praksis. Ateliervirksomheten på skolen og det tilknyttede offentlige visningsstedet bidrar til å forankre den kunstdidaktiske praksisen i en, for elevene, gjenkjennelig lokal kontekst. Langsiktige og gjensidig forpliktende prosesser mellom skole og kunstnere ser ut til å åpne for deltakelse, fordypning, utforskning og dialog for alle involverte aktører. Samarbeidet mellom lærer og kunstner styrkes over tid og det vokser fram en refleksiv, integrert og levedyktig kunstdidaktisk strategi som skaper eierskap i begge sektorene (Ulrichsen, 2014, 2015). Det empiriske materiale 


\section{G. O. Ulrichsen}

avdekker et behov for å rette økt oppmerksomhet mot den betydningen et felles refleksjonsrom, på tvers av fagdisiplinene, kan ha i forhold til å øke bevissthet rundt verdien av en integrert kunstpraksis i en pedagogisk kontekst.

TOs og den videregående skolens samarbeid viser hvordan kunstdidaktisk praksis kan tilføre mønster av performativitet, erfaring og utforskning av ambivalens i arbeid med meningsskaping. Gjennom å la elevene artikulere, bearbeide og forhandle kontrasterende verdigrunnlag og motstridende erfaringer, og ta i bruk sin egen levde erfaring gjennom praktisk og estetisk samhandling, åpnes det for et engasjement rundt elevens egen rolle og plass i samfunnet. Imidlertid kreves det mer enn isolerte kunstmøter og opplevelser for å oppnå transformasjon og dybdelæring. Innenfor rammen av stabile relasjoner møtes strukturelle utfordringer, og det åpnes rom der kunstnerisk praksis og pedagogiske prosesser møtes i fruktbare prosesser. Kultursosiologen Dyndahl beskriver kunstfagdidaktikk som kulturdidaktikk (Dyndahl, 2011). Hans poeng er at det ikke finnes en nøytral kunstfagdidaktikk - strukturene, organiseringen og modellene speiler og reproduserer kunstsyn, ideologi og verdivurderinger. Kunstfagene konstituerer på denne måten estetiske arenaer for konstruksjon og utøving av kulturell identitet og makt. Ulike didaktiske forhold kan, ifølge forfatteren, dermed utgjøre signifikante forskjeller når det gjelder hvilken mening som blir en dominerende maktfaktor og hvilken mening som blir marginalisert. I artikkelen argumenterer jeg for at både grunnskoleopplæringen og kulturskolen kan få økt betydning i et demokratisk utviklingsperspektiv gjennom å prøve ut alternative organisasjonsmodeller som trekker veksler på didaktiske forhold i TOs og den videregående skolens samarbeid.

På et overgripende nivå ser samarbeidet ut til å vise vei for en didaktikk som bygger på: 1) utforskende læring i organisk utviklede undervisningsforløp med ekspressive mål, 2) relasjonell forankring som inviterer alle aktører til å gå inn i risikofylte, uforutsigbare møter sammen, 3) læringsprosesser og kunnskapsproduksjon med lokal tilknytning, 4) estetisk erfaring for å vekke empati og engasjement, 5) kollektive prosesser framfor individuell produksjon og 6) uttrykk og deltakelse i det offentlige rom. Det er videre behov for å beskrive og analysere hvordan disse prinsippene gir seg utslag i en konkret didaktikk i TOs praksis. Det vil da også bli mulig å vurdere om samarbeidet mellom TO og skolen kan innebære en didaktisk nyorientering innenfor kunst- og håndverksfagets og kulturskolens undervisningspraksiser der kunstmøter inngår som en viktig del i tverrfaglige læringsprosesser. I og med at denne artikkelen først og fremst ivaretar et kunstnerperspektiv er det i et tverrfaglig perspektiv betimelig å inkluderer lærerens perspektiver i større grad.

$\AA$ vende oppmerksomheten mot en nærlesning av didaktikken som utøves vil gjøre det mulig å undersøke hvordan praksis påvirkes av en interkulturell pedagogik ${ }^{9}$ der

\footnotetext{
${ }^{9}$ Ifølge Pirjo Lahdenperä handler interkulturalitet om alle typer av meningsskapende kulturer: etniske, religiøse, språk-, tanke-, kjønns- og klassemessige. En gruppe vil alltid inneholde ulike kulturer i mer eller mindre grad (Lahdenperä 2004, s. 29). Jeg har valgt å bruke interkulturell framfor det mer brukte flerkulturell fordi det tydeligere impliserer aspekter av endring og dynamikk.
} 
elevenes ulike og mangfoldige erfaringsbakgrunn anses som grunnleggende ressurser i lærings- og endringsprosesser. Dette vil også gi innsikt i om deltakelse i TOs praksis kan bidra til å styrke elevenes evne til å manøvrere mellom de ulike forventninger, verdiladede vurderinger og normative virkelighetsoppfatninger de møter i spennet mellom hjem, skole, fritidsarenaer og samfunnsinstitusjoner.

\section{Referanser}

Aagre, W. (2003). Ungdomskunnskap. Hverdagslivets kulturelle former. Bergen: Fagbokforlaget.

Allern, S. (2011). Er det plass for kunstfag i skolen etter pisa? Kunstløftet, Maitekst 2011. Hentet 01.02.2016 fra http://kulturradet.no/kunstloftet/vis-artikkel/-/asset_publisher/wS73/content/kl-artikkel-allern-maitekst

Alvesson, M., \& Sköldberg, K. (2008). Tolkning och reflektion: Vetenskapsfilosofi och kvalitativ metod (2. utg.). Lund: Studentlitteratur.

Aure, V., Illeris, H., \& Örtegren, H. (2009). Konsten som läranderesurs: Syn på lärande, pedagogiska strategier och social inklusjon på nordiska konstmuseer. Skärhamn: Nordiska akvarellmuseet.

Aure, V. (2013). Didaktikk - i spennet mellom klassisk formidling og performativ praksis. InFormation - Nordic Fournal of Art and Research, 2(1), 1-24. Hentet 10.02.2016 fra http://dx.doi.org/10.7577/if.v2i1.611

Aure, V., Berge, O. K., \& Hylland, O. M. (2012). Infrastruktur for kvalitet? Evaluering av seanse - senter for kunstproduksjon (TF-rapport nr. 309). Hentet 01.04.2013 fra http://www.tmforsk.no/publikasjoner/filer/ 2172.pdf

Bamford, A. (2012). Kunst- og kulturopplcering i Norge 2010/2011: Sammendrag på norsk av kartleggingen «Arts and cultural education in norway». Bodø: Nasjonalt senter for kunst og kultur i opplæringen.

Biesta, G. \& Lawy, R., (2006). Citizenship-as-practice: The educational implications of an inclusive and relational understanding of citizenship. British fournal of Educational Studies, 54(1), 34-50. Hentet 10.02.2016 fra http://www.jstor.org/stable/3699294

Bjerkestrand, K. B., Brahmachari, S., Haraldsen, H. M., Ingul, S., \& Sogne Møller, A. (2016). Narrativ identitet : Drama- og teaterpedagogisk praksis $i$ interkulturell kontekst. Oslo: Tell forlag.

Bjørnsen, E. (2012). Inkluderende Kulturskole. Utredning av kulturskoletilbudet i storbyene. Prosjektrapport nr. 5/2012. Kristiansand: Agderforskning.

Bourriaud, N. (2007). Relasjonell estetikk. Oslo: Pax.

Breivik, J.-K., \& Christophersen, C. (2013). Den kulturelle skolesekken. Oslo: Kulturrådet.

Bresler, L. (2008). The music lesson. I J. G. Knowles \& A. L. Cole (Red.), Handbook of the arts in qualitative research: perspectives, methodologies, examples and issues (s. 225-235). Los Angeles: Sage Publications.

Cohen Evron, N. (2007). Conflict and peace: Challenges for arts educators. I L. Bresler, M. Espeland \& E. Olsen (Red.), International handbook of research in arts education (s. 1031-1044). Dordrecht: Springer.

Costantino, T., \& Garber, E. (2007). Social issues in art and visual/material culture education. I L. Bresler, M. Espeland \& E. Olsen (Red.), International handbook of research in arts education (s. 1055-1065). Dordrecht: Springer.

Dyndahl, P. (2011). Kulturteoretiske perspektiver på musikkdidaktisk forskning. I P. Dyndahl, T. O. Engen \& L.I. Kulbrandstad (Red.), Lererutdanningsfag, forskning og forskerutdanning. Bidrag til kunnskapsområder $i$ endring (s. 185-221). Vallset: Oplandske bokforlag.

Helguera, P. (2011). Education for socially engaged art: a materials and techniques handbook. New York: Jorge Pinto Books.

Illeris, H. (2011). Giv ungerne nogle kulturelle kompetencer! - kunstpædagogik og samtidens kulturelle ordener. Kunstløftet, Maitekst 2011. Hentet 01.01.2016 fra http://kulturradet.no/vis-arkivartikkel/-/asset_ publisher/U1Cc/content/kl-artikkel-2011-illeris-maitekst

Kaihovirta-Rosvik, H. (2009). Images of imagination: An aesthetic approach to education (doktorgradsavhandling). Åbo: Åbo Akademi Press.

Kalsnes, S. (2011). Trenger vi kunstpedagogikken? Kunstløftet, Maitekst 2011. Hentet 01.02.2016 fra http:// kulturradet.no/kunstloftet/vis-artikkel/-/asset_publisher/wS73/content/kl-artikkel-kalsnes-maitekst

Kleppe, B. (2013). Kultur møter kulturmøter. Kulturskolebruk blant innvandrere. Prosjektrapport nr. 310. Telemark: Telemarksforskning.

Knowles, J. G. \& Cole, A. L. (2008). Arts-informed research. I J. G. Knowles \& A. L. Cole (Red.), Handbook of the arts in qualitative research: Perspectives, methodologies, examples and issues (s. 55-70). Los Angeles: Sage Publications. 


\section{G. O. Ulrichsen}

Lahdenperä, P. (2004). Interkulturell pedagogik $i$ teori och praktik. Lund: Studentlitteratur.

Riessman, C. K. (2008). Narrative methods for the human sciences. Los Angeles: Sage.

Rasmussen, B. (2012). Kunsten å forske med kunsten: Et blikk på kunnen ut fra praksis-teori-relasjonen. I R. G. Gjærum \& B. Rasmussen (Red.), Forestilling, framføring, forskning: Metodologi $i$ anvendt teaterforskning (s. 23-50). Trondheim: Akademika.

Rasmussen, B. (2013). Fra erfaring til refleksiv kunnskap: Sentrale premisser i drama og i praksisledet forskning. I A.-L. Østern, G. Stavik-Karlsen \& E. Angelo (Red.), Kunstpedagogikk og kunnskapsutvikling (s. 261-270). Oslo: Universitetsforlaget.

Samuelsen, A. M. (2013). Formidling av Kunst til barn og unge (2. utg.). Oslo: Universitetsforlaget.

Sava I. (1995). Den konstnärliga inlärningsprocessen. I I. Porna \& P. Väyrynen (Red.), Handbok om grundundervisning $i$ konst (35-50). Helsingfors: Finlands kommunförbund, Utbildningsstyrelsen.

Selander, S. (2008). Tecken för lärande - tecken på lärande. Ett designteoretisk perspektiv. I A.-L. Rostvall \& S. Selander (Red.), Design för lärande (s. 28-44). Stockholm: Norstedts akademiska förlag.

Sidorkin, A. M., \& Bingham, C. (2004). No education without relation. New York: Peter Lang.

Spurkeland, J. (2011). Relasjonspedagogikk: Samhandling og resultater $i$ skolen. Bergen: Fagbokforlaget.

Ulrichsen, G. O. (2014). Deltakende kunstnere på en pedagogisk arena. En dialogbasert studie som ser på hvordan relasjonelle aspekter utgjør rammeverk for kunstdidaktisk utøvelse (mastergradsavhandling kunstfagdidaktikk). Trondheim: PLU, NTNU.

Ulrichsen, G. O. (2015) Tenthaus Oslo - deltakende kunstnere på en pedagogisk arena. Hentet 01.12.2015 fra http:/www.kulturradet.no/kunstloftet/vis-artikkel/-/tenthaus-oslo-intervjuet-av-gry-o-ulrichsen

Ulrichsen, G. O (2016). Kunstner i skolen - deltaker eller gjest. Bedre Skole, 3, 48-53. Hentet 10.11.2016 fra https://www.utdanningsforbundet.no/upload/Tidsskrifter/Bedre\%20Skole/BS_3_2016/7724-BedreSkole0316-Ulrichsen.pdf

Ulvund, M. (2015). In the age of the teaching artist? What teaching artist are and do. InFormation - Nordic Fournal for Art and Research, 4(1), 19-36. Hentet 10.09.2016 fra http://dx.doi.org/10.7577/if.v4i1.1369

Østern, A.-L. (2013). Kunstneren som veileder for barns kunstmøte. I A.-L. Østern, G. Stavik-Karlsen \& E. Angelo (Red.), Kunstpedagogikk og kunnskapsutvikling (s. 19-36). Oslo: Universitetsforlaget. 